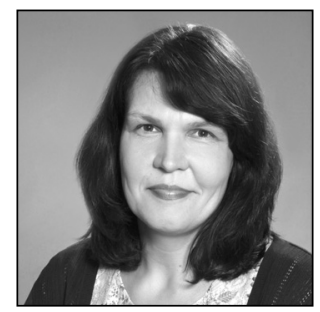

Merike Varusk

Judge, Harju County Court

\title{
Company Board Members' Liability and Prerequisites for it in Bankruptcy Proceedings
}

\section{Introduction}

This article deals with the question of what kind of liability can be applied to a company board member in bankruptcy proceedings for infringement of his duties. In analysis of these duties and any infringements thereof, the board member's actions can be assessed for purposes of enabling determination, in the course of the bankruptcy proceedings, of whether the company's insolvency was caused by a grave error in management by the board member, a deed possessing constituent elements of an offence, or another factor. When management errors are present, there is reason to ask whether a board member's liability follows. If liability does follow, there will arise a need to ascertain what kind of liability can be applied. Prerequisite for the above-mentioned course of action will be analysis of the board member's duties. A separate object of scrutiny is whether there are duties that do not entail liability.

As a general rule, infringement of a board member's duties entails liability for indemnification, since between a company and its board member there is a mandate-like relationship due to which infringement entails contractual civil liability. While dealing with civil liability, the article does not refer to the creditor's right to assert a claim on the basis of the law of torts, since this piece takes as its starting point the company board member's liability that proceeds from the entrustment relationship between him and the company. In addition, one must scrutinise whether the infringement of the board member's duties would justify application of penal liability. Thirdly, one must examine in which cases imposing of prohibition on business through application of bankruptcy law would be justified.

\section{Duties whose infringement entails liability}

The legal relationship between a company and a board member may be regarded as an entrustment in the sense stipulated by $\S 619$ of the Law of Obligations Act ${ }^{*}$ (LOA). In determination of the nature of the relationship between a company and a board member thereof, provisions of the Commercial Code, Law of Obligations Act, General Part of the Civil Code Act, etc. must be taken into consideration, along with the company's charter, decisions of its governing bodies, and the contract concluded between the company and the board member. The main element of this relationship is the board member's duties. For consideration of these matters, the present paper categorises the relevant duties via hierarchical division into general and

Law of Obligations Act. - RT I 2001, 81, 487; 29.11.2013, 4. 
other duties, with the latter, in turn, being divided into 'main' and 'specific' obligations ${ }^{{ }_{2}}$. Such categorisation is followed also by the legislation in vigour-for example, the classification of general obligations is derived from the provisions of the General Part of the Civil Code Act, Law of Obligations Act, and Commercial Code, and the main and specific duties are also regulated by various provisions of the Commercial Code (CC).

Since the board member has a legal relationship only with the company, he can infringe only his duties toward the latter. From the standpoint of bankruptcy proceedings, this article regards the board member's duties to the company and their infringement as infringement of the duties derived from the obligation (entrustment) between them since in the framework of such a relationship the provisions dealing with noncontractual illegal damage cannot be applied ${ }^{*} 3$.

In the case of a claim being asserted against a company board member in bankruptcy proceedings, the bankruptcy trustee must prove, among other things, that the board member has infringed his duties ${ }^{*}$. Hence, to assert a claim against a board member, the bankruptcy trustee will have to ascertain the board member's duties under the law, the contract, etc., in order to be able to assess whether the damage or an illegal deed was caused by infringement of the board member's duties.

\subsection{General obligations}

A board member's general obligations are the duty of care and the duty of loyalty. According to $\$ 35$ of the General Part of the Civil Code Act ${ }^{*}$ (GPCC), members of the company's governing body (board and council members) must fulfil the obligations derived from the law or the charter with the diligence that can normally be expected of a board member and must be loyal to the company. The board member is bound to act in accordance with the obligation to remain loyal to the company and to apply the necessary diligence in line with the nature of the mandate (see the LOA’s $\S 620$ (1) and the CC's $\S 187$ (1); $\$ 315$ (1); and $\S 327$ (1)). Along with the duty of loyalty, the duty of care is at the very top of the pyramid in the hierarchy of a board member's obligations, where it encompasses the most important and most general guidelines for behaviour that the board member must rely on in his actions ${ }^{*}$. In view of the importance of the general obligations, the author will expand upon them more thoroughly in this article.

The duty of care is the responsibility or the legal obligation of a person or organization to avoid acts or omissions (which can be reasonably foreseen) to be likely to cause harm to others* 7 . In view of the duty of care, the leader must make use of his skills in such an assiduous and diligent manner as any reasonable person would apply in similar circumstances ${ }^{*}$. The board being the only body to represent the company's interests, it is accorded ample scope for action for reaching of the goals established by the charter ${ }^{*}$.

In order to assess whether the board member has fulfilled his duties with due diligence, one must make the judgement on the basis of the field of activities of the company in question, its size, the board member's personal qualities, and the concrete nature of the tasks (mandate) to be fulfilled. In evaluation of the duty of care, an objective standard must be followed. That standard is derived from $\$ 620$ (2) of the LOA, according to which the follower of the mandate is a professional. Hence, the author is of the opinion that if the board member's knowledge and experience are insufficient for fulfilment of his obligations or if he fails to perform his obligations for another reason, this constitutes a violation of his obligations.

2 P. Varul et al. Äriühingu juhtorganid [Company Management Bodies]. Äripäeva Kirjastus 2005, p. 53; T. Tiivel. Äriühingu juhtorgani liikme kohustused ja vastutus [Obligations and Liability of a Member of a Company Management Body]. MA thesis, Tartu University 2004, p. 13

3 CCSCd 3-2-1-18-08.

CCSCd 3-2-1-197-13.

General Part of the Civil Code Act. - RT I 2002, 35, 216; 6.12.2010, 12.

P. Varul et al. (see Note 2), p. 54.

See the lexicon of economic terms on the Internet at http://www.businessdictionary.com/ (most recently accessed on 18.07.2014).

8 J.N. Gordon, M.J. Roe. Convergence and Persistence in Corporate Governance. Cambridge University Press 2004, p. 338. DOI: http://dx.doi.org/10.1017/CBO9780511665905.

9 B. Kropff, J. Semler. Münchener Kommentar zum Aktiengesetz [Commentaries on Limited Liability Companies]. Munich: Verlag C.H. Beck / Verlag Franz Vahlen 2004, p. 448. 
In following the duty of care, the board member must fulfil his duties in line with the bona fide principle set forth in $\S 32$ of the GPCC, taking into consideration first and foremost the interests of the company ${ }^{*}{ }^{10}$.

The duty of loyalty brings in the question of trust, since the board member has ample rights of representation to act in the name of the company, to assume proprietary obligations, and to exercise his rights. The aim of the duty of loyalty is to avoid exploitation of other shareholders or partners by the shareholders or partners who lead the company or control it ${ }^{* 11}$. The duty of loyalty encompasses the board member's duty to avoid the influence of his personal interests upon the consequences of his decisions and to avoid conflict of interests between himself and the company. Board members must not use their position to gain personal profit and benefit or other personal advantages; in dealings with the company and the owners, they must give precedence to the interests of these over their own ${ }^{*}$. The duty of loyalty is expressed first and foremost by means of a non-competition obligation, confidentiality, obligation to avoid conflict of interests, and monetary financing prohibition.

Under the non-competition obligation, a board member must not, without the partners' or council's approval, be a self-employed entrepreneur in the field of activity of the relevant limited company, be a partner in a general partnership active in the same field as the limited company; or be a member having unlimited liability or board member of a trust, except when the companies belong to the same business group (see $\S 185$ (1); §312 (1); and $\S 324$ (1) of the $\mathrm{CC}^{* 13}$ ). The monetary financing prohibition is an absolute prohibition, since the company must not give loans to its board members. The same is true of credit agreements and financially equivalent transactions. The aim of the above-mentioned is unambiguous exclusion of the realisation of loan-like withdrawals, of whatever sort, and to preclude tax evasion. The duty of confidentiality is related to the company board member's duty to keep the company's trade secrets (these consist of intellectual property such as know-how, information on the processes or systems involved, and other confidential information that gives its owner a competitive advantage and whose unauthorised disclosure would harm the owners' interests) and must encompass the possibility of hindering the disclosure of such information under their control ${ }^{* 14}$. The content and volume of the trade secrets depends on each individual company, since such factors as the specifics of the field of activity of the company in question mean that the trade secrets may encompass very different kinds of information. The duty to avoid conflict of interests refers to the board member's duty to, while exercising his civil rights and performing his civil duties, follow the bona fide principle, which entails the board member's duty to avoid in his actions conflict between the interests of the limited company and his own ${ }^{*} 15$. The subjecting of the board member's activities to surveillance by the company's council is seen as a suitable measure for avoiding conflict of interests since transactions that surpass the limits of everyday economic affairs must be authorised by the council.

The primacy of general obligations, especially that of the obligation to apply diligence, as a prerequisite for application of liability to a company board member, is emphasised also by the legislation currently in vigour, since filing a claim for compensation against a company board member is properly justified if the damage in question has been caused by infringement of the board member's duties and the board member will have the opportunity to be exempted from liability if able to prove having performed his duties with the diligence that can be expected from a decent entrepreneur (see the CC's $\$ 187$ (2) and $\$ 315$ (1)). The case law has assumed the same position ${ }^{* 16}$. It follows from the foregoing that, in order to be exempted from liability, the company board member will have to prove that, while fulfilling the duty of care, he has acted in accordance with the needs of the specific company involved, followed the objective standards, and fulfilled his duties derived from the law and his contract with diligence and in good faith, whereas if there is suspicion that the board member has infringed the duty of loyalty, he will have to prove that he has not breached the trust accorded him.

10 P.L. Davies (ed.). Gower's Principles of Modern Company Law, sixth edition. London: Sweet \& Maxwell 1997, p. 610; CCSCd 3-2-1-67-03, p. 23.

11 J.N. Gordon, M.J. Roe (see Note 8), p. 339.

12 T. Tiivel. Piiratud vastutusega äriühingu juhatuse liikme lojaalsuskohustus [The Duty of Loyalty of a Board Member of a Limited Liability Company]. - Juridica 2001/IV, pp. 225-233.

13 Commercial Code. - RT I 1995, 26, 355; 23.12.2013, 27.

14 CCSCd 3-2-1-108-o8; dictionary of business terms at http://www.businessdictionary.com/.

5 CCSCd 3-2-1-67-03, p. 23.

6 CCSCd 3-2-1-197-13. 


\subsection{Main obligations}

The main obligations are a set of other obligations that, in essence, go hand in hand with the leadership of a company and are not regulated in detail by the law. Main obligations are hierarchically subordinated to the general duty of care and loyalty. The main obligations of a company board member are planning, organising, management (leadership), and monitoring. The principles of division stated here were set forth in the 18th century ${ }^{* 17}$ and have been complemented more recently ${ }^{* 18}$.

Planning is a leadership function that is related to determining the goals for future achievements ${ }^{*}$. Planning is the most important of the main obligations, since it is oriented toward planning of the enterprise's economic affairs in the future. This is formulated as a plan ${ }^{* 20}$. If the company has a council, planning shall be their duty (see the CC's §316), drawing up of short-term plans may be among the duties of a board member. Organising is a direct continuation from planning: it is a leadership function that aids in structuring the company and co-ordinating the employees' behaviour in accordance with the goals set in the planning $^{* 21}$. Implementation of the company's plans is related to its everyday economic affairs and is the task of the company's board. Management (leadership) is 'people management', involving organising people and motivating them to work together in order to reach certain goals ${ }^{{ }^{22} 2}$. The function of management comprises important processes such as communication with the vendors, production work, and provision of services, alongside guaranteeing solid financial management ${ }^{*}{ }^{2}$. The decisions on the management of the company are made by the council members, while a board member is in charge of the company's economic affairs to the extent that this is not within the competence of the council or general meeting. Monitoring (surveillance) is a systematic process that enables the leaders to regulate the organisational activities and bring them into accordance with the established plans, goals, and standards ${ }^{* 24}$, and its aim is to obtain feedback on the enterprise's industrial performance. The task of the board member is to monitor the company's activities, and the fulfilment of that duty is supervised by the council. A final matter to be considered here is representation. The company is represented by the board member, whose right of representation in relation to third parties is without condition, except if the company's board members share a common right of representation and a note to that effect has been made in the trade register.

Proper fulfilment of the main obligations is important since, for example, a business plan compiled in a superficial manner and failure to fulfil the duty to monitor may lead to failure to detect persistent losses that could lead to the company's insolvency.

\subsection{Specific obligations}

A company board member's specific obligations too are subordinated to the duties of care and loyalty. Specific obligations, together with the main obligations, belong to the other obligations; they are differentiated by the fact that the main obligations are of a more general nature while the specific obligations are narrower and concretely delineated.

The author of the present article is of the opinion that the most important of the specific obligations is the company board member's obligation to organise the accounting, since the correct performance of

17 H. Mintzberg. The Nature of Managerial Work. New York; Evanston, ; San Francisco; London: Harper \& Row, Publishers 1973, p. 1.

18 R.L. Daft, D. Marcic. Management: The New Workplace, sixth edition. Cengage Learning 2009, p. 8; E. Werlauff. EUCompany Law: Common Business Law of 28 States, second edition. DJØF Publishing 2003, p. 394; R. Alas. Juhtimise alused [Basics of Managing]. Tallinn: Kirjastus Külim 2004, p. 11; P. Varul et al. (see Note 2), p. 82.

19 R.L. Daft, D. Marcic (see Note 18), p. 8.

20 R. Brody. Effectively Managing Human Service Organisations, third edition. USA: SAGE Publications 2004, p. 9; J.H. Donnelly, Jr et al. Fundamentals of Management. Homewood, Illinois; Boston: Irwin 1992, p. 142.

21 R.L. Daft. New Era of Management, second edition. Thomson South-Western 2008, p. 308.

22 Jones, M. Accounting for Non-Specialists - West Sussex: Cardiff Business School, John Wiley \& Sons, Ltd 2002, p. 370; J.J. du Plessis et al. Principles of Contemporary Corporate Governance. New York: Cambridge University Press 2005, pp. 6-7. - DOI: http://dx.doi.org/10.1017/CBO9780511813481.

23 R.S. Kaplan, D.P. Norton. Strategy Maps: Converting Intangible Assets into Tangible Outcomes. Boston: Harvard Business School Press 2004, pp. 65-77; K. Bender, K. Ward. Corporate Financial Strategy, second edition. Great Britain: Martins The Printers 2003, pp. 41-42.

24 R.L. Daft (see Note 21), p. 454. 
that duty is a prerequisite for performance of many other duties of a company board member, while also being a good way to get an overview of the company's economic situation. The aim of that duty is to fulfil the requirements of accountancy and disclosure ${ }^{2} 25$. One of the tasks involved in the accountancy obligation is to create a system of early warning ${ }^{{ }^{2} 26}$. The obligation to convene a meeting of partners or shareholders guarantees the informing of the owners. Commercial law lays down the foundations for convening a meeting, of which the most important must be deemed to be the duty, proceeding from $\S \S 176$ and 301 of the Commercial Code, to convene a meeting of partners/shareholders in the event of the company's assets falling below the limit stipulated by the law. If the company has become permanently insolvent, the board member is bound to file a bankruptcy petition. The aim of filing a bankruptcy petition is to inform the legal public in order to warn them of an insolvent limited company ${ }^{* 27}$. The bankruptcy filing must be presented to the court immediately and not later than 20 days after the emergence of insolvency. There is also an obligation of accountancy to a higher governing body. Board members are bound to inform the company partners or shareholders about the company's activities and to grant them and the council access to the company's documents. In addition, there are obligations derived from the charter or work contract. In establishment of the relationship between the board member and the company, the provisions of the law must be followed, as must the company's charter, the provisions of the work contract concluded between the company and the board member, and concretisation of the board member's duties via decisions made by the council or the board. The list of specific duties provided here is not exhaustive.

\section{Liability of a company board member in bankruptcy proceedings}

\subsection{Specifics of liability in bankruptcy proceedings}

A board member of a legal person is liable for infringement of his duties regardless of whether that legal person is declared bankrupt. The present article deals with the situation wherein the legal person has been declared bankrupt and the main question is that of what the board member is liable for. The foundations for the board member's liability are essentially the same as in the situation in which the legal person has not been declared bankrupt. However, there are certain distinctions. In bankruptcy proceedings, when civil legal responsibility is applied, whether a grave management error has been made is of importance since that serves as a basis for determination of whether or not the bankruptcy trustee will be bound to file a claim for compensation against a board member. The bankruptcy-related offences listed in the Penal Code presume that a legal person has become bankrupt (these being causing insolvency, infringement of the duty to file for bankruptcy. Application of prohibition on business presumes that a legal person is declared bankrupt.

\subsection{Civil liability}

In bankruptcy proceedings, a specific element involved with respect to applying civil responsibility lies in the need to, in addition to following the ordinary way of filing a claim against a board member, establish the presence of a grave management error. If a board member has committed a grave management error, the bankruptcy trustee is bound to seising of a court against a board member who has infringed his obligations (BA, $\left.\$ 55(3)^{3}\right)$. Application of liability in cases of a slighter management error is not excluded either.

In filing of a claim against a company board member, the following presumptions must be relied on: that the board member has violated his duties (see the CC's $\$ 187$ (1) or §315 (2), or the GPCC's §35), material loss to the company has emerged or is about to emerge (under the LOA's $\$ 127$ (1) and §128), there is a causal relationship between an infringement and damage (see the LOA, §127 (4)), and the board member is liable for infringement of his duties-he has not followed the standards of diligence of a decent entrepreneur (see the second sentence of the CC's $\S 187$ (2) and also $\$ 315$ (2)). The burden of proof is divided in such a

\footnotetext{
J.N. Gordon, M.J. Roe (see Note 8), p. 333.

B. Kropff, J. Semler (see Note 9), p. 447.

Ibid., p. 482.
} 
way that, when asserting his claim, the bankruptcy trustee will have to prove that the board member has infringed his duties and that precisely these infringements have caused the damage to the company to occur. After that, the board member, in his turn, will have the opportunity to prove that he has been acting with the diligence expected from a decent entrepreneur ${ }^{*_{2} 8}$.

In addition to the general presumptions for filing a claim against a board member, the bankruptcy trustee will have to ascertain whether the board member has committed a grave management error since in the bankruptcy proceedings the bankruptcy trustee is bound to file a claim for compensation in the event of a grave management error (under the BA's $\left.\$ 55(3)^{3}\right)$. In view of that, the author will proceed to assess in which cases it is possible to claim that a board member's grave management error is present. In evaluation of a possible grave management error, the main question is whether it would be well-justified to apply liability to a board member. In the case of infringement of a duty, a management error is present too, so the question arises of whether there is a good reason to file a claim for compensation against a board member who has infringed his duties. A precondition for applying liability in the event of a grave management error is a possibility of filing a claim for compensation from a board member who has infringed his duties. Application of liability in cases of a slighter management error is not excluded either. No-one has set a lower limit from which a management error may be considered a grave one. Instead, this has been left to the case law to evaluate. At present, what there is of the latter is relatively vague.

According to the author of this article, in dealing with a grave management error committed by a board member, the presence and quantity of damage plays an important part. For example, the author is of the opinion that if the board member has given an unsecured loan, there is grave negligence since in such a situation a debtor may fail to fulfil his duties, and in such cases it may also turn out that the debtor has no assets that would enable him to satisfy the claim. It is this author's view that a management error that has caused substantial damage may be regarded as a grave management error since substantial damage will have a serious impact on the company's economic indicators and could bring about payment difficulties for the company that in the worst case might cause the company to become insolvent. The size of the company is a decisive factor since the sum of damage that may cause insolvency for a small company may not have a substantial impact on a big enterprise. In determination of what constitutes a grave management error, it is also important to ascertain whether a management error that is being blamed on a board member presents the constituent elements of an offence.

In practice, in cases involving a claim for compensation against a board member, there is frequently a problem with the bankruptcy trustee, as applicant, having to prove that an infringement of duties by the board member and ensuing damage have taken place: often the relevant evidence is lacking, or later on, during the action, new evidence emerges that excludes the board member's liability. In practice, quite often there is also the problem that the bankrupt company's documentation handed over to the bankruptcy trustee in the course of the bankruptcy proceedings turns out to be deficient.

In the process of filing a claim, the breeder documents for accounting are of decisive importance, as documents that form the basis of every entry confirming an economic transaction (see \$6 (4) of the Accounting Act), so the bankruptcy trustee should, when taking control of the bankrupt entity's accounting documents, be diligent and fixate in detail all documents to be taken over in the takeover act, while also applying to the court for administering an oath to the debtor's board member (see $\S \S 19$ and 86 of the Bankruptcy $\mathrm{Act}^{* 29}$, or BA) about the data presented to the court on the assets, debts, and economic or vocational operations being correct to the best of his knowledge. In such cases, a board member will have a hard time presenting new evidence later in the course of the action, since he will have to state a cause for previously having presented incorrect data to the court or the bankruptcy trustee, for doing the latter may result in liability for perjury (under $\$ 320$ of the Penal Code). The author is of the opinion that if the debtor's board member is able to specify a convincing cause for not having presented the bankrupt company's accounting documents earlier, the costs of any legal proceedings or other expenses (such as expenses of ordering an expert evaluation prior to filing of a claim) resulting from the board member's failure to present the evidence in a timely fashion should still be left to be borne by the board member whose actions caused these expenses. The author is of the opinion that leaving of the expenses to be borne by the board member is justified by the fact that the debtor's board member is obliged to organise the accounting (under the CC's $§ 183$

\footnotetext{
CCSCd 3-2-1-197-13, p. 14.

29 Bankruptcy Act. - RT I 2003, 17, 95; 9.5.2014, 14.
} 
and $\$ 306$ (4)), and belated presentation of documents in the situation wherein a board member previously asserted under oath to the court that the data presented to the court are correct indicates that the debtor's board member had not organised the accountancy properly-in other words, he did not have a proper overview of the documents or concealed them during hand-over to the bankruptcy trustee or to the court. Hence the author is of the opinion that if infringement of the obligation of accounting by the board member has entailed damage, whether within or beyond the framework of legal proceedings, the damage caused must be compensated for by the board member who has infringed his duties.

If no damage has emerged as arising in consequence of the board member's infringement of his duties, there is reason to deliberate whether to apply penal or bankruptcy liability to him.

\subsection{Penal liability}

Infringement of duties by a company's board member may entail penal liability. Such liability belongs to the domain of so-called economic offences, with the aim being to regulate the economic environment and to prevent offences related to it. The board member's penal liability is well justified if the infringement of his duties (by action or inaction) is listed in the Penal Code as an offence. Infringements of board members' duties are mentioned as company-related offences (in the Penal Code ${ }^{*} 30$, or PC, in $\S \S 377-381^{1}$ ), as are offences related to bankruptcy proceedings ( $\mathrm{PC}, \S \S 384-385^{1}$ ). At the same time it is also possible to punish the board member who has infringed his duties for crimes against property, such as misappropriation (PC, $\S 201)$.

Of board members' duties, the Penal Code stipulates punishments mostly for the specific duties, such as: infringement of the duty to convene the meeting of partners or shareholders (PC, §380), infringement of the duty to organise the accounting ( $\mathrm{PC}, \S 381^{1}$ ), and infringement of the duty to file for bankruptcy in case of insolvency (PC, $\left.\S 385^{1}\right)$. At the same time, infringement of general obligations-such as breaching the obligation of loyalty or the obligation to honour trade secrets (PC, §377) or causing insolvency through infringement of the duty to apply diligence (PC, \$384)-also constitutes an offence, according to the Penal Code.

If the debtor turns out to have committed a deed with constituent elements of an offence in connection with the emergence of insolvency, the court or the bankruptcy trustee will have to inform the prosecutor or the police in order for them to decide upon the initiation of criminal proceedings (under the BA's §28 (1)). Regardless of the fact that many complaints of an offence are filed in relation to causing insolvency and other offences resulting from infringement of duties of company board members, these have not led to conviction of persons having committed deeds with elements of an offence, since most criminal prosecutions are terminated on account of expiry or application of opportunity. In this author's opinion, the latter shows that the state so far has not contributed enough means to investigate offences related to insolvency and directed against companies; also, nothing has been done for some years now to enhance the competency of investigators who deal with economic offences. Still, constant criticism and practical need have led to the establishment of the Economic Offences Bureau (under the jurisdiction of the Central Criminal Police), whose task it is to investigate economic offences of a more serious kind. The author is of the opinion that such an approach is very welcome but does not justify decriminalisation of the above-mentioned economic offences or eliminate the need to enhance the investigative capacity also with respect to lesser economic offences.

At present, plans are being made to introduce, with a draft act (DA 554) ${ }^{*}{ }^{31}$, changes to the Penal Code Implementation Act, to decriminalise several bankruptcy-related offences and offences directed against companies. Under the proposed amendments, infringement of the duty to convene the meeting of partners or shareholders (PC, §380) would cease to be an offence. It is this author's opinion, however, that the latter provision is an important measure for protecting the investors (partners and shareholders), in order to guarantee the timely involvement of the owners and to give the investors the opportunity to take decisions pertaining to their assets. In the bankruptcy proceedings, the owner (partner or shareholder) is not a creditor through a claim over a share or a sum of money paid for a share, due to which he will be left without protection by exclusion from the regulation of $\S 380$ of the PC. Section 384 of the Penal Code does not

Penal Code. - RT I 2001, 61, 364; 14.1.2014, 10.

31 Draft act for introducing amendments to the Penal Code and other legislative acts related to it, available at http://www. riigikogu.ee/?op=ems\&page=eelnou\&eid=78433b29-8b2f-4281-a582-oefb9631e2ad\& (most recently accessed on 30.6 .2014$)$. 
guarantee protection to the investors in a situation wherein the meeting of partners, shareholders, or cooperative members has not been convened in a due manner but infringement of the duty has not necessarily resulted in a substantial decrease in the debtor's solvency or in his insolvency.

There is also the intention to eliminate, through the prospective changes of DA 554, the offence of failure to file for bankruptcy (from the PC's $\S 385^{1}$ ). A company board member is bound to, in the course of 20 days after the emergence of persistent insolvency, file for bankruptcy (under the CC's $\S 180\left(5^{1}\right)$ and $\S 306$ $\left(3^{1}\right)$ ). In evaluation of the insolvency, the indicator for equity capital (net assets) has been used that reflects the difference between the entity's assets and commitments (see \$3 3) of the Accounting Act ${ }^{*}{ }^{2}$ ). According to $\$ 1$ (3) of PC, the legal person of the debtor is insolvent also when the debtor's assets do not cover his commitments and the debtor's economic situation indicates that this state or a similar one is not temporary. The above-mentioned regulations seem to indicate that earlier negative equity capital-i.e., the situation wherein the commitments exceed the company's assets and such a situation is not temporary-shows that the company has become permanently insolvent. The Supreme Court has explained that the mere fact of the company's net assets constituting less than half of the share capital or equity capital does not necessarily mean that the company is persistently insolvent in the sense of the bankruptcy law and that there is reason to prosecute a company board member on the basis of $\S 385^{1}$ of the Penal Code ${ }^{*} 33$. The author of this article agrees with that viewpoint since in some cases negative equity capital does not imply the persistent insolvency of the company. For example, such a situation may emerge in cases of long-term commitments. A company's commitments are divided into short- and long-term ones (in Appendix 1 to the Accounting Act), which means that long-term commitments too are shown as commitments-for example, a bank loan that is being paid back in equal monthly instalments over the span of 30 years. In the case described here, the value of the purchased assets should restore the balance between assets and commitments and guarantee the existence of positive equity capital. However, there may be cases in which the value of the assets purchased has for some reason decreased substantially yet the company continues to be able to pay the monthly instalments and engage in sustainable activities. In such cases, regardless of the negative equity capital, the company is not persistently insolvent.

The duty to file for bankruptcy is a board member's specific obligation whose infringement (failure to file for bankruptcy in a timely manner or failure to file altogether) creates a situation wherein, as a result of the delay in filing for bankruptcy, the debtor's assets decrease and, in consequence of this, creditors' possibilities of satisfying their claims also diminish. In the event that the company board member fails to file for bankruptcy when this should be done, a situation arises in which some creditors will file for bankruptcy or the company will be divested at the registrar's initiative (the CC's \$59). Because, according to the data provided by the Ministry of Justice, at least two thirds of legal persons' bankruptcy proceedings, for reason of lack of assets, do not proceed to judgement and bankruptcy proceedings not proceeding to judgement results in there being no civil liability of the company's governing bodies related to filing of a compensation claim or insolvency liability through application of prohibition on business, the only possibility for prosecution of the company board member who has infringed his duties is the application of penal liability. It is the author's opinion that if this too fails to follow, the situation will motivate the board members of companies in economic difficulties to delay filing for bankruptcy until the company in question is broke, which would bring about a situation wherein the bankruptcy proceedings do not proceed to judgement and, therefore, neither civil nor insolvency liability follows for the board member. Such a situation, in its turn, would corrupt the economic environment, reduce opportunities for honest entrepreneurs, and corrupt the investment climate and involvement of foreign investments.

In the explanatory statement accompanying the amendment, the decriminalisation of infringement of the duty to file for bankruptcy is justified by, among other arguments, the reasoning that the Supreme Court has found that determination of the presence of constituent elements of an offence in pre-trial and judicial proceedings has become extremely difficult since it would always presume commissioning of difficult and time-consuming use of expertise to establish the moment of emergence of insolvency. Also, according to the explanatory statement, the failure to file for bankruptcy does not have to be punishable in nature since the board member's direct liability emerges regardless in cases of filing for bankruptcy in an untimely manner. The author is of the opinion that the prospective change is not well grounded, since the aim of $\S 385^{1}$

\footnotetext{
32 Accounting Act. - RT I 2002, 102, 600; 13.3.2014, 50.

33 CCSCd 3-1-1-49-11.
} 
of the Penal Code is to guarantee the creditors the opportunity to get maximal satisfaction of their claims that would be afforded by timely filing for bankruptcy. With every day of delay in filing for bankruptcy, the assets available for satisfying the creditors' claims decrease and the claims filed against the person in question grow (for example, with respect to the calculation of overdue charges, the emergence of additional commitments). Also, the exclusion of what is described in $\S 385^{1}$ of the PC from the list of offences would give the wrong signal to those active in the economic environment, as if failure to file for bankruptcy when one should were not a condemnable deed. In this author's opinion, the case law ${ }^{*} 34$ has specified well how the public prosecutor's office must check the presence of constituent elements of an offence.

In cases of infringement of the duty to file for bankruptcy, it is important that, since the responsible persons are often dispossessed, application of civil liability often does not bring the desired results. Also, the legislation in vigour does not allow application of prohibition on business in cases wherein the proceedings do not proceed to judgement, for which reason the only possibility for prosecution of an irresponsible board member involves his conviction for an offence. The relevance of $\$ 385^{1}$ of the Penal Code is demonstrated also by the fact that in the legislation of other countries liability for an analogous offence is considered important; for example, failure to file for bankruptcy in a timely manner is classed as an offence in Germany.

By way of supplementary penal punishment, an occupation ban (under the PC's §49) or prohibition of engaging in enterprise in general (under the PC's $\$ 49^{1}$ ) may be stipulated. These are similar in essence to the prohibition on business that is found in insolvency law.

\subsection{Bankruptcy liability}

Such sanctions as are stipulated in bankruptcy law may be regarded as bankruptcy liability. The board member's liability is stipulated in cases wherein he would infringe his duties during the bankruptcy proceedings-for example, will not fulfil the duty to provide the information or will infringe the ban on insolvency assets' disposal. By way of application of liability to a board member for infringements committed earlier, it is possible to require prohibition on business (see the BA's §91). The application of prohibition on business presumes infringement of the company board member's duties, and here, unlike with the presumptions associated with application of civil liability, whether or not the infringement has led to damage emerging is immaterial.

Bankruptcy law differentiates between the prohibition on business during the bankruptcy proceedings and after them. Prohibition on business during the proceedings (under the BA's §91 (2)) is applicable until the end of the bankruptcy proceedings. The prohibition on business in vigour during the bankruptcy proceedings obtains from the issuing of the court order until the end of bankruptcy proceedings. According to the case law, the function of the prohibition on business during the proceedings is the preventive protection of third persons, in order to prevent the subject of the prohibition on business from committing new offences or causing damage to third parties. The prohibition on business may be applied only to a person who is very likely to have committed a crime while managing a now-bankrupt legal person but has not yet been convicted (i.e., when there is a well-founded suspicion of a crime) and when there is a serious danger that, should prohibition on business not be applied, he may commit new offences of a similar kind. ${ }^{*} 5$

Prohibition on business after the proceedings (see the BA's §91 (3)) is applicable to the subjects related to the legal person (under the BA's §19 (1) and (3)), provided that the debtor or the person to whom the prohibition on business is about to be applied has been convicted on the basis of a verdict having entered into vigour for an offence related to bankruptcy, enforcement procedure, a tax offence, or an offence listed in $\S 380$ or $381^{1}$ of the Penal Code. The prohibition on business after bankruptcy proceedings may last for up to three years after the end of said proceedings (see the BA's §91 (3)). In application of prohibition on business after bankruptcy proceedings, it must be ensured that the person is not punished twice for the same offence-that is, that there will be no conflict with the ne bis in idem principle as stipulated in §23 of the Constitution. That means that a person who has been punished for a bankruptcy- or enforcementprocedure-related offence or a tax offence when, by way of supplementary penal punishment, an occupation ban or prohibition to engage in enterprise has been applied shall not be punished a second time through application of prohibition on business after the bankruptcy proceedings.

\footnotetext{
CCSCd 3-1-1-85; 3-1-1-49-11.

CCSCd 3-2-1-124-09, p. 15 .
} 
In the Estonian legislation, the occupation ban and the prohibition to engage in enterprise are formally and in substantive law supplementary penal punishments, while prohibition on business after the end of the proceedings is in substantive law a supplementary penal punishment, but formally a bankruptcy-linked restriction. Only guilt may be the foundation for applying penal coercive measures, but for non-penal coercive measures a danger emanating from the person in question shall suffice ${ }^{*} 36$.

The Supreme Court has found that the main aim with the occupation ban during bankruptcy proceedings (see the BA's $\S 91$ (2)) is for it to be a preventive coercive measure ${ }^{*} 37$. This provision must be interpreted in a restrictive manner since the prohibition on business intensely strike at the person's fundamental rights: the freedom to choose a job (laid down in §29 (1) of the Constitution), the freedom to pursue an economic or business activity (see the Constitution's §31), and the freedom to dispose of one's property (see the Constitution's $\$ 32$ (2)). Restrictive interpretation is justified also by the fact that measures similar to the prohibition on business may be applied to a person for penal purposes only on the basis of $\S 49$ or $49^{1}$ of the Penal Code. According to 991 (2) of the BA, mere suspicion of a misdemeanour or the possibility of emergence of damage is not sufficient.

Although the author agrees with the Supreme Court's view in that the application of prohibition on business strikes at the core of a person's fundamental rights, the author is of the opinion that in the situation wherein a company board member has seriously infringed his duties and thereby caused substantial damage to the company and its creditors, the application of prohibition on business is well-justified. Although, as the practice of the Supreme Court shows, application of the prohibition on business has become more complicated, the author remains of the opinion that the restrictions on this measure are well-founded; we are dealing with limitations to a person's freedom to pursue business activity, so prohibition on business should not be applied without good reason. German and Finnish legislation do not know the application of prohibition on business in bankruptcy proceedings at all; instead, it is applied in these systems as a criminal punishment. For example, the German penal code allows imposing the occupation ban on a person ${ }^{*}{ }^{3}$ for up to five years. If it is found after this that the danger to business is still present, the occupation ban may be applied for life. According to Finnish legislation regarding the prohibition on business, the duration of the prohibition on business may be $3-7$ years ${ }^{*} 39$. If a person who belongs to the group of those to whom the prohibition on business may be applied ${ }^{*}{ }^{\circ}$ has committed a serious offence, the Finnish legislation on prohibition on business (\$20) stipulates the duty to carry out an investigation in order to establish whether there is a reason to apply prohibition on business to said person. The investigation shall be carried out by the police on the basis of the prosecutor's request. The author is of the opinion that, in view of the Supreme Court having referred to the deficiencies in the application of the prohibition on business, following the model of the practices of the other countries, such as Germany and Finland, should be considered in the course of the revision of the regulations pertaining to application of prohibition on business.

At the same time, the author is the opinion that substantial restriction of the prohibition on business is not founded since it would cause loss of the preventive influence: there would be no more fear of application of the prohibition on business. In this author's opinion, the application of the requirement of prohibition on business would be justified also, for example, in the event that infringement of the duty to file for bankruptcy is decriminalised or in the situation wherein the bankruptcy trustee has filed a claim for compensation against a board member who has infringed his duties. The regulations regarding prohibition on business should be changed in such a way that it would be possible to apply it also to board members against whom, on account of their being dispossessed, it would make no sense to file a claim.

In the author's opinion, the application of prohibition on business would be well-grounded also in the case of the bankruptcy proceedings not proceeding to court. At present, company board members are interested in proceedings not progressing to court handling, since this does not leave the court with a reason to nominate a bankruptcy trustee, whose duty it is to ascertain any infringement of board members' duties and to

\footnotetext{
36 A. Tubin. Menetlusjärgne ärikeeld: kas pankrotiõiguslik piirang või karistusõiguslik lisakaristus? [Prohibition on Business after Legal Proceedings: Bankruptcy-linked Restriction or Supplementary Penal Punishment? ]. - Juridica 2012/6, pp. 442-449.

37 CCSCd 3-2-1-124-09.

38 The German Criminal Law, or Anordnung des Berufsverbots, § 70 of the Ciminal Code of Germany.

39 Laki liiketoimintakiellosta (Law of Prohibition on Business of Finland), Section 5, available at http://www.finlex.fi/fi/laki/ ajantasa/1985/19851059 (most recently accessed on 18.7.2014).

$40 \quad$ Laki liiketoiminatakiellosta (ibid.), Section 2.
} 
demand application of the associated liability. Also, because of lack of assets, the creditors are not interested in filing claims against the board members of a company that has become bankrupt. Since at present the practice of applying penal responsibility to the board members is seldom seen and there is the intention to decriminalise several economic offences, the author is of the opinion that there are grounds for changing the possibilities for application of prohibition on business in such a way that it would be possible to apply this prohibition on business to a board member also in case the bankruptcy proceedings do not proceed to court. Also, the bankruptcy law should be complemented in such a way that in case the bankruptcy proceedings do not lead to court proceedings, it would still be possible to file for compensation against the board members who have infringed their duties. The above-mentioned measures would make it possible to reduce considerably the quantity of bankruptcy proceedings that do not reach the courts.

\section{Conclusions}

Analysis of company board members' obligations makes it possible to evaluate a board member's actions and thereby determine, during the bankruptcy proceedings, whether the company's insolvency was caused by a grave management error by the board member in question, a deed with constituent elements of an offence, or another element and consequently apply the liability entailed by the infringement of one's obligations.

According to the principles for applying civil liability, in the event of a grave management error having been committed by a board member, the bankruptcy trustee must file for compensation. If the board member has infringed his obligations but no damage has emerged, there is reason to deliberate whether reason exists to apply penal or bankruptcy liability.

Infringement of a board member's duties is often also an offence for which the penal code stipulates a liability. Penal liability for a board member who has infringed his obligations follows if his deed corresponds to the constituent elements of an offence stipulated by the Penal Code and he has been proved guilty.

The presumptions for application of bankruptcy liability-in the form of prohibition on business after the bankruptcy proceedings-also include the person's conviction; for prohibition on business to be applied during the bankruptcy proceedings, there must be a well-founded suspicion of a crime. It is this author's opinion that current practice in interpretation of the prohibition on business does not fulfil its aims, since it has been substantially restricted. Application of the prohibition on business should be amplified in such a way that it would guarantee board members' responsible behaviour. 